ИСТОРИЈСКИ ЧАСОПИС, књ. LXVII (2018) стр. 207-222

THE HISTORICAL REVIEW, vol. LXVII (2018) pp. 207-222

УДК: 94(497.11):327(44:497.11),,1861““

\author{
Урош ТАТИһ ${ }^{*}$ \\ Историјски институт \\ Београд
}

\title{
ПОЛИТИКА ФРАНЦУСКЕ ПРЕМА КНЕЖЕВИНИ СРБИЈИ У ВРЕМЕ ОДРЖАВАЊА ПРЕОБРАЖЕНСКЕ СКУПШТИНЕ 1861. ГОДИНЕ ${ }^{* *}$
}

\begin{abstract}
Ancmpaкm: Савети руског министра спољних послова Александра Михаиловича Горчакова и француског министра спољних послова Едуара Тувнела (Antoine Edouard Thouvenel) дати специјалном изасланику српске владе Јовану Мариновићу за време мисије у Петрограду децембра 1860, и у Паризу фебруара 1861, и неуспех у директним преговорима с Портом 1860-1861. године одлучујуће су утицали на Правитељство да убрзано приступи промени унутрашњег уређења земље доношењем специјалних закона. Слични Тувнеловим били су и предлози које је 1861. француски амбасадор у Цариграду маркиз Шарл Лавалет (Lavalette, Charles Jean-Marie Félix, marquis de) дао специјалном изасланику у преговорима с Портом Илији Гарашанину. Охрабрен ставовима Париза и Петрограда, кнез Михаило Обреновић ће, не мењајући га формално, стварно изменити Устав Кнежевине Србије из 1838. године.
\end{abstract}

Кључне речи: Преображенска скупштина, кнез Михаило, Тувнел, Тасти, Француска, Србија, Турска, Порта.

На Преображенској скупштини одржаној у Крагујевцу 18. августа 1861. године кнез Михаило је изнео програм који је прихваћен, а потом су изгласани изузетно значајни закони о Савету, Скупштини, народној војсци и порезу на иметак. ${ }^{1}$ На тај начин је практично извршена уставна реформа,

*urostatic@yahoo.com

* Рад је настао као резултат истраживања на пројекту Министарства просвете, науке и технолошког развоја Републике Србије Европа и Срби (1804-1918). подстиияаји и искушења европске Модерне (Ев. бр. 177031).

1 Сви датуми наведени у тексту, осим ако то није посебно назначено, дати су према новом календару. 
пошто су ван снаге стављене многе одредбе Устава из 1838. године. ${ }^{2}$ Скуп тих закона чини Михаилов политички и административни систем. ${ }^{3}$

Законом (Устројенијем) о Државном савету онемогућено је мешање Порте у унутрашња питања Србије. Уколико би саветници учинили кривично дело судио им је кривични суд, чиме је анулиран члан 17 Устава и право турске владе да арбитрира у неспоразумима између кнеза и Савета. По овом закону српски владар је стекао важно право којим је пробијао оквире вазалности: „Једино кнез заступа и представља Србију према страним државама. Он закључује уговоре и прави конвенције о чему извештава Савет чим околности допусте (члан 10)“. Закон о Народној скупштини није битније поправио државноправни положај Србије, осим што питања устава и наследства престола без Скупштине нису могла бити решавана. Од свих донесених најважнији је био Закон о устројству народне војске, која је створена „за одбрану земље и за одржање права Кнежевине“. ${ }^{4}$ Образовање народне војске је било главни разлог за незадовољство Порте које ће достићи врхунац у турском бомбардовању Београда 1862. године. Процедуру суспендовања Устава из 1838. године Михаило је наставио и наредних година доношењем још неких битних закона. Законом о устројству изентралне државне управе (1862) министри су стављени под кнежеву власт. Они више нису морали бити бирани из редова саветника. Српски агенти у Цариграду и Букурешту добили су звање заступника. У државном шематизму за 1863. годину први пут се чланови владе називају министрима а представништва у иностранству заступништвима. Кнежевина је постала модерна држава са звањима која познаје Запад. Поред поменутих донети су и закони о локалној управи и чиновницима и измењен Закон о наследству престола. На тај начин „Турски устав“ је суспендован стварно али не и формално, па је постојао предлог да се закони кнеза Михаила назову некодификовани Преображенски устав. „Стари устав као символ вазалности остао је и даље као мост на суву који је нови ток реке обишао“ у тежњи ка пуној независности. ${ }^{5}$

2 Р. Љушић, Михаило Обреновић (1823-1868), Србија 19. века. Изабрани радови, Београд 1994, 130.

3 Р. Љушић, Историја српске државности. Србија и Црна Гора - нововековне српске државе, књ. II, Нови Сад 2001, 137-138.

4 Б. Поповић, Дипломатска историја Србије, Београд 2010, 301.

5 Милован Миловановић је писао да су закони кнеза Михаила „нов устав Србије“ - „Државно право (белешке са предавања на Великој школи)“, Државно право и друге уставноправне студије, Београд 1997, 151-152, 156; С. Јовановић, Друга влада Милоша и Михаила, Београд 1990, 358, 359, 365, 377; М. Поповић, Борба за 
Рад Скупштине су са великом пажњом пратили сви страни представници, али не у самом Крагујевцу, већ из Београда. Око вароши је постављен војни кордон да би било спречено комуницирање с унутрашњошћу. Од странаца, само три француска агента су успели да остану у Крагујевцу и прате рад Скупштине. ${ }^{6}$ Као што се могло и претпоставити, највећу узнемиреност су показали аустријски вицеконзул Конрад Васић и британски конзул Лонгворт. ${ }^{7}$ Треба, међутим, нагласити да је Лонгворт, не знајући да је кнез приступио припремама нацрта закона који ће бити изнети пред Скупштину, саветовао Порти сазивање народног представништва. На тај начин биле би предупређене многе невоље које су могле задесити Турску. Михаило је могао прогласити независност Србије поступајући по вољи народа.

Почетком октобра, Правитељство је сматрало потребним да преко заступника у Цариграду званично обавести Порту и представнике гарантних сила о одлукама Скупштине. Такође, председник владе Филип Христић се потрудио да у том погледу пружи детаљна објашњења и француском конзулу Ежену Тастију (Eugène Tastu). Сам кнез је изјавио Тастију да су српске тежње сасвим законите и да је његов главни циљ да помири унутрашњу слободу земље са њеним међународним обавезама. Михаило није могао да дозволи даље нарушавање унутрашње аутономије Србије. Више од двадесет година су новине које је уводила Порта наносиле све већу штету законодавству Кнежевине и погоршавале њен унутрашњи и спољашњи положај. ${ }^{8}$

У свом извештају Тувнелу Тасти је изразио сумњу да ће објашњења Правитељства, у шта је веровао Христић, наићи на добар пријем код Порте и гарантних сила. Мале земље не могу да убеде велике дворове у законитост одређених корака само тиме што ће указивати на своја права и интересе. Француски конзул је сматрао да је Христић олако прихватио као законите различите мере, чије увођење је зависило само од кнежеве воље. Михаило је добар, благ и искрен владар али склон да се превари, осредњих способности и претерано суревњив када је у питању његов владалачки ауторитет. Кнез схвата унутрашњу аутономију и сизеренство Порте над Србијом на сличан начин на који Баварска гледа

парламентарни режим у Србији, Београд 1939, 32; М. Павловић, Преображенски устав, први српски устав, Крагујевац 1997, 156, 189, 207, 227, 283-284, 289, 292.

6 Љ. П. Ристић, Велика Британија и Србија (1856-1862), Београд 2008, 190-191.

7 Љ. Алексић, Став Франиуске према Србији за време друге владе кнеза Милоша и Михаила (1858-1868), Београд 1957, 51.

8 Archives du Ministère des Affaires Etrangères - Paris (AMAE), Turquie-Belgrade 13, № 49, анекс уз извештај, Тасти Тувнелу, Београд, 11. октобра 1861. 
на своје односе с Аустријом или онако како владар неке од малих држава Немачке конфедерације схвата свој положај према Пруској. Председник српске владе се није много трудио да наведе разлоге за уношење измена у Устав из 1838. године, а што је изазвало незадовољство Велике Британије и Аустрије. Нерасположење Порте, на шта се у Србији гледа с омаловажавањем, представљало је много већу опасност него што се то наизглед чинило. Иако користи свој положај да отежа постојање и развитак Кнежевине, турска влада нема на исту превише утицаја. То је главни узрок лоших српско-турских односа. Тасти није сматрао мудрим што је Христић упућивао Порти индиректне претње, обнављајући у име Скупштине захтев за спровођењем одредби садржаних у хатишерифу из 1830. године на који је Турска гледала као да није ни донет. На овај начин српска влада је само озловољила Порту. Конзул је сматрао да би било корисно на то скренути пажњу Правитељству. Оно што је Тасти највише замерао српским званичницима је што предузете мере нису поткрепили довољно јаким разлозима. ${ }^{9}$ Упркос бројним примедбама у погледу измене Устава француски конзул није јавно критиковао кнеза и владу.

Највеће изненађење у Београду изазвало је држање руског конзула пуковника Александра Георгијевича Влангалија и владе у Петрограду. За време Мариновићеве мисије, Горчаков је унапред обећао Правитељству подршку ако спроведе измену Устава заобилазним путем. На то се позвао и српски председник владе. Међутим, Христићу је објашњено да Русија у том тренутку није могла предвидети да ће овакво тумачење Горчаковљеве изјаве бити употребљено против њених интереса и да је ситуација сада знатно измењена. У новом саопштењу руски министар је поручио да би у погледу промене Устава Правитељство требало претходно да се споразуме с осталим силама. ${ }^{10}$

9 Исто.

${ }^{10}$ Исто. Неколико дана пред Михаилов одлазак у Крагујевац, у двору у Топчидеру одржана је седница којој су присуствовали кнез, чланови владе, поједини саветници и руски конзул. Влангали је Михаилу и Правитељству посебно скренуо пажњу на неколико чланова уставног нацрта српског правника Ђорђа Стојаковића који су представљали основу закона донетих на Преображенској скупштини. Први члан се тицао кнежевог права да представља Србију према Порти и другим државама и самостално закључује споразуме са њима. Другим чланом је предвиђено да сви странци са пребивалиштем у Србији буду стављени под српску јурисдикцију, која може бити ограничена законом или споразумима. Руски конзул је јасно изнео да, упркос томе што је Кнежевина Србија аутономна у оквиру Османског царства, не може да присваја ова овлашћења независних држава, јер би то изазвало дипломатски скандал у Цариграду и код осталих гарантних сила. 
Одлуке Преображенске скупштине су, како се могло и очекивати, изазвале велико незадовољство Порте. Крајем септембра, на конференцији сила у Цариграду сазваној ради решавања питања Дунавских кнежевина турска влада је изнела на расправу и овај проблем. ${ }^{11}$ У донесеним законима Али-паша је видео нов доказ непријатељских намера Србије према сизерену. Највише жалби било је због Закона о устројству народне војске којим је мала српска милиција, чији је задатак био очување унутрашњег поретка, претварана у моћну оружану силу. Иако је и пре тога, од повратка Обреновића, било доста разлога за подозрење Порте према Србији, дотадашње манифестације српско-турских супротности ипак нису суштински реметиле њихове односе, могле су се објаснити на колико-толико прихватљив начин, па и ублажити када затреба. Са овим реформама то, међутим, није био случај. Истима је Србија од Турске начинила нов велики корак ка еманципацији без сагласности сила и против воље сизереног двора и најављено је уређење војске какву имају суверене државе, очигледно у циљу припреме рата за независност. ${ }^{12}$ Велики везир је сматрао да циљ Правитељства може бити само агресија или прекид веза са Турском. Охрабрен подршком Аустрије и Велике Британије, Али-паша је уложио протест против одлука Скупштине, извештавајући гарантне силе да неће бити признате све док их српска влада не поднесе на оцену Порти и силама. Он је затражио од великих дворова Европе да у том смислу изврше притисак на Михаила. ${ }^{13}$

Током читавог трајања спора с Портом, званични Париз је био на страни Србије. Министар Тувнел је сматрао да измене Устава из 1838. године могу изазвати примедбе турске владе ако не због основе, а оно због форме у којој су извршене, то јест путем посебних закона. Међутим, он је био мишљења да мере Правитељства не представљају никакву опасност за Османско царство. Због тога је преко турског амбасадора у Паризу и француског представника у Цариграду саветовао Порти умереност. Конзул у Београду требало је да поступа у складу с општим упутствима која су му дата средином марта за време Мариновићеве

Влангали је истакао мишљење да пред Скупштину никако не буде изнесен на усвајање пројекат новог устава, већ да, према ранијим упутствима из Петрограда буду изнесени закони којима би суштински, али не и формално био измењен хатишериф из 1838. године (Д. Леовац, Србија и Русија за време друге владе кнеза Михаила (1860-1868), Београд 2015, 67-69).

11 Л. Ранке, Србија и Турска у XIX веку, Београд 1879, 459.

12 Ž. Đorđević, Čukur-česma 1862. Studija o odlasku Turaka iz Srbije, Beograd 1983, 17.

${ }^{13}$ Г. Јакшић, В. Вучковић, Спољна политика Србије за владе кнеза Михаила. Први балкански савез, Београд 1963, 82. 
мисије. ${ }^{14}$ Поред подршке коју је пружала Србији, влада у Паризу је покушавала да спречи стварање нове кризе на Истоку. Након окончања експедиције француске војске у Сирији и затварања сиријског питања у јуну 1861. године, Француској је ради интервенције у Мексику била потребна сагласност Велике Британије. Знајући да је она на страни Турске, Тувнел је настојао да избегне сваку расправу с владом у Лондону. Отправник послова француске амбасаде у Цариграду гроф Албер Лалман (Lallemand, Marie Charles Henri Albert, comte de) је скренуо пажњу Алипаши да Тувнел није наклоњен његовој идеји да тражи од великих сила општу осуду мера Правитељства. ${ }^{15}$ На конференцији у Цариграду велики везир није успео у својој тежњи због уздржаног става француског и отпора пруског и руског амбасадора. ${ }^{16}$ Али-паша је покушавао да добије од сила сагласност за оружану интервенцију у Влашкој и Молдавији због намере две кнежевине да ускоро прогласе уједињење. Општа осуда поступака српске владе била би само увод у оно што је велики везир након тога настојао да учини. Интервенцију у Дунавским кнежевинама он је желео да прошири и на Србију. ${ }^{17}$

Француска, Русија, Пруска и Италија одбиле су да подрже Портин протест. С друге стране, влада у Бечу је у потпуности усвојила образложења званичног Цариграда. Аустрију су највише узнемиравале тврдње турских министара да су одлуке Преображенске скупштине имале за циљ да омогуће помагање устанка у Херцеговини. Она је ове догађаје одмах довела у везу с Гарибалдијевим револуционарним плановима на Балкану. У прилог наводима владе у Бечу ишло је стварање српске народне војске. ${ }^{18}$ Аустријски министар спољних послова гроф Јохан Рехберг је у ноти послатој амбасадорима у Паризу, Лондону, Берлину и Петрограду изнео став да спор између Порте и Правитељства треба да буде решен у њиховим директним преговорима, а на основу постојећих хатишерифа и уговора. Влада у Бечу желела је на Балкану одржање status quo-a. ${ }^{19}$ Због тога је она покушала да издејствује заједничку дипломатску интервенцију сила у Београду. У томе је могла рачунати на сарадњу Велике Британије која је

\footnotetext{
${ }^{14}$ AMAE, Turquie-Belgrade 13, № 5, Тувнел Тастију, Париз, 23. септембра 1861.

${ }^{15}$ Исто, Turquie 352, No 144, Лалман Тувнелу, Терапија, 9. октобра 1861.

16 Л. Ранке, нав. дело, 460.

${ }^{17}$ Ј. Ристић, Спољашњи одношаји Србије новијега времена, књ. I-III, Београд 1887-1901; II, 89.

${ }^{18}$ Г. Јакшић, В. Вучковић, нав. дело, 99.

${ }_{19}$ В. Поповић, Политика Франиуске и Аустрије на Балкану у време Наполеона III, Земун-Београд 1925, 115.
} 
сматрала да су намере италијанских родољуба према Балкану део ширег плана за изазивање немира у Турској. ${ }^{20}$

У разговору с Тувнелом аустријски амбасадор у Паризу принц Рихард Метерних је добио темељно образложење зашто је влада у Паризу одбацила Портин захтев. Француски министар је приступио изношењу ставова у погледу сваке од три тачке Портине оптужбе и пружио одлучну подршку Србији. С обзиром на то да кнез нема мушког потомка, а да наследника не може одредити без одобрења сизерене силе, Порта по питању наследства кнежевског достојанства у породици Обреновића не би требало да буде сувише узнемирена. Министар је подсетио да је право наследства било признато још кнезу Милошу. Што се тиче стварања народне војске, турска влада такође нема много разлога за бојазан. Према Тувнеловим обавештењима ову формацију је чинио један врло ограничен кадар народне гарде без плате и оружја. Што се тиче одлука о принадлежностима Савета, министар је у потпуности делио мишљење Правитељства. Сада ово привилеговано тело, које је у прошлости било средиште свих сплеткарења уперених против владе, више неће моћи по својој вољи смењивати и постављати владаре. Тувнел се оградио, рекавши да је ово само његово лично мишљење, да званични одговор владе у Тиљеријама, као ни самог цара, још увек није прецизиран. ${ }^{21}$ Метерниху је, међутим, било јасно да се ни Наполеон III ни његова влада неће изјаснити другачије. ${ }^{22}$ Схвативши да има мало изгледа да Тувнел усвоји мишљење Аустрије, Метерних је скренуо пажњу саговорнику да је пренебрегао основну чињеницу: хатишерифи и Устав Србије били су под гаранцијом сила потписница Париског уговора. Својим мерама, Правитељство је прекршило овај међународни правни акт. Тувнел је рекао да одговор на питање да ли је кнез прекорачио границе предвиђене уговорима може дати тек након подробног испитивања које би спровела посебна комисија француске владе. Он никако није био наклоњен Портиној идеји да питање изнесе пред нову конференцију сила у Цариграду или пред европску комисију која би радила у Србији. Сматрао је да је свакој од сила требало оставити слободу да одреди свој став у том погледу. Аустријског амбасадора је нарочито изненадила Тувнелова изјава да Михаило не би посегнуо за оваквим мерама да је Порта изашла у сусрет његовим

20 Ж. Ђорђевић, Српска народна војска. Студија о уређењу народне војске Србије 1861-1864, Београд 1984, 28.

${ }^{21}$ Архив Српске академије наука и уметности (АСАНУ), И 16/4, И XLVIII, Метерних Рехбергу, Париз, 7. децембра 1861.

22 љ. Алексић, нав. дело, 52. 
упорним молбама и уклонила турску полицију из Београда. ${ }^{23}$ Министар је покушао да докаже да српски захтев није био неумерен. Турски гарнизони у Србији представљали су обележје суверенитета Порте, што је њу требало да задовољи. У том случају не би постојала бојазан од отцепљења Кнежевине. ${ }^{24}$

За разлику од Тувнела, влада у Бечу није с оптимизмом гледала на кораке Правитељства. Она је сматрала да је Михаило амбициозан владар који гаји симпатије према виновницима немира у суседним турским провинцијама. Затварајући очи пред првим корацима на његовом опасном путу, Француска ће пружити Кнезу охрабрење да настави да задире у туђе право. Стога би било много боље да влада у Паризу скрене пажњу Михаилу да скретањем са законитог пута доводи у питање развитак и благостање земље. Одговарајући на Метернихове примедбе, Тувнел је обећао да ће у том смислу саветовати опрезност Правитељству. ${ }^{25}$

Француска није успела у намери да одврати Аустрију од супротстављања одлукама Преображенске скупштине. Након разговора Тувнела и Метерниха, Рехберг је почетком децембра 1861. године предложио Великој Британији да заједно с владом у Бечу упути протест Београду. У Лондону је предлог одмах прихваћен. Представницима две силе, Лонгворту и Васићу, била су послата истоветна упутства. У њима је указано на повреде нанете правима Турске и гарантних сила. Посебне критике изазвала је одредба члана 10 новог закона о Савету по којој је само кнез имао право да представља српски народ пред страним државама. Иста је за обе силе била доказ о решености Кнежевине да постане потпуно независна. Правитељство ће доказати да заслужује покровитељство Европе само ако се врати на пут законитости и поштује границе Устава за чије одржање гарантују силе. Лонгворт и Васић су почетком јануара 1862. године предали новом председнику владе Гарашанину меморандуме састављене на основу добијених упутстава. ${ }^{26}$

Француски министар и амбасадор у Цариграду прихватили су овом приликом мишљење конзула Тастија. Он је сматрао да није упутно да званични Париз свој став у вези с одлукама Преображенске скупштине изнесе Правитељству у исто време када аустријски и британски представник буду уручивали протестну ноту. На основу тога књажеска влада би могла стећи утисак да се Француска придружила демаршу Беча

\footnotetext{
23 АСАНУ, И 16/4, И XLVIII, Метерних Рехбергу, Париз, 7. децембра 1861.

24 Л. Ранке, нав. дело, 463-464.

25 АСАНУ, 16/4, И XLVIII, Метерних Рехбергу, Париз, 7. децембра 1861.

${ }^{26}$ Г. Јакшић, В. Вучковић, нав. дело, 99-100.
} 
и Лондона. Стога је амбасадор маркиз Лионел Мутје (Moustier, Marie François René Lionel, marquis de) телеграфисао Тастију да мишљење званичног Париза саопшти Правитељству у форми и у тренутку када он то буде сматрао за сходно. ${ }^{27}$

Због држања Француске Порта је према њој све више показивала неповерење. Оно је било приметно приликом сваког говора великог везира и сераскера о српском и црногорском питању. Углавном су коментарисани пријатељска осећања француске владе према Црној Гори и наклоност конзула Тастија према Правитељству. У истом духу говорили су и аустријски и британски амбасадор. ${ }^{28}$

Са своје стане, влада у Београду је у почетку врло одлучно и аргументовано одговарала на оптужбе Беча и Лондона. Она то свакако не би чинила да није уживала подршку Париза и Петрограда. Поред дипломатске заштите коју су Француска и Русија пружиле Србији у Цариграду, кнез Михаило и Илија Гарашанин су добијали конкретне савете од конзула двеју сила. Гарашанин није одговорио на британскоаустријски протест све док није чуо мишљење руског, француског и пруског представника. Конзул Тасти је имао толики утицај у Београду да га је чаршија сматрала господаром ситуације. ${ }^{29}$ Гарашанин је доказивао да су одлуке Преображенске скупштине засноване на одредбама Париског уговора којим је Србији призната пуна унутрашња аутономија. За Турску није од важности да ли ће се српски народ користити својим правом и бирати кнеза од случаја до случаја или ће тачно утврдити начин за његов избор који ће бити важећи за све време владавине једне династије. Председник владе је подсетио Лонгворта и Васића да је о стварању народне војске одлучено још 1848. и 1854. године и да тада Порта није имала примедбе. Скупштинска одлука је имала за циљ да отклони страх у народу од нагомиланих турских трупа дуж граница Србије. Укидање члана 17 Устава је било неизбежно јер саветници више нису могли уживати привилегију да не подлежу судској власти. Ова одредба била је узрок свим дотадашњим превратима у Србији. ${ }^{30}$ Гарашанин је сматрао да Порта није требало да се обраћа силама јер је пуних седам месеци, за време његовог боравка у Цариграду, имала прилике да размотри та питања и споразуме се непосредно с Правитељством. ${ }^{31}$ Из дипломатске расправе

\footnotetext{
27 AMAE, Turquie 353, № 15, Мутје Тувнелу, Пера, 20. јануара 1862.

${ }^{28}$ Исто, о 30, Мутје Тувнелу, Пера, 12. фебруара 1862.

29 Љ. П. Ристић, нав. дело, 200.

${ }^{30}$ Г. Јакшић, В. Вучковић, нав. дело, 100.

31 љ. Алексић, нав. дело, 53.
} 
Србија је изашла окуражена: први пут се догодило да су Француска и Русија, у директном сучељавању са Портом, Великом Британијом и Аустријом, помогле свом снагом, мада с очигледном намером да смире, а не да продуже и радикализују спор, што је у Београду свакако уочено. ${ }^{32}$

Влада у Паризу је стога желела да спор између Србије и туркофилских сила буде што пре окончан. Због тога је она саветовала кнезу помирљивије држање. ${ }^{33}$ У новој вербалној ноти упућеној британској и аустријској влади, Правитељство је образложило одлуке Скупштине у умереном тону. Изражено је уверење да деловање српских власти никада није изашло из оквира права признатих хатишерифима и чланом 28 Париског уговора и да стога оне нису заслужиле прекоре. У исто време, Тувнел је у писмима упућеним у Лондон и Беч изразио наду да ће тамошње владе прихватити објашњења Правитељства. Он је дао налог Мутјеу да у истом смислу делује у Цариграду. ${ }^{34}$ Након ових једновремених корака Француске и Србије, британски амбасадор Хенри Булвер је отворено изразио жељу да питање буде решено мирним путем, а влада у Лондону је привремено одустала од даљих приговора. Због недовољне подршке својих савезница које нису желеле даље заоштравање спора с Кнежевином, Порта се морала тренутно задовољити објашњењима српског представника у Цариграду. ${ }^{35}$

На држање сила према одлукама Преображенске скупштине одлучујуће је утицала општа ситуација у европским крајевима Турске. Аустрија и Велика Британија су биле пре свега забринуте због италијанских и грчких планова о подизању устанка на Балкану. Ове силе су знале за постојање веза између Гарибалдијевих агената и власти у Црној Гори. Било је познато да кнез Никола Петровић пружа подршку устанку у Херцеговини, а постојала је и претња од његовог отвореног уласка у рат против Порте. Врење се такође осећало у Албанији и Бугарској, одакле су у Србију пребегавале читаве породице. Аустрија и Велика Британија су стално сумњичиле Кнежевину да пружа помоћ устаничком покрету у Херцеговини и подстиче немире у Бугарској. Скупштинске одлуке представљале су за туркофилске силе наговештај активнијег учешћа Србије у балканским догађајима.

Највећи страх Аустрија и Велика Британија су осећале због подршке коју је Кнежевини пружала Француска. Највише незадовољства

32 Ž. Đorđević, Čukur-česma 1862, 18.

${ }_{33}$ Л. Ранке, нав. дело, 465.

${ }^{34}$ AMAE, Turquie 353, No 10, Тувнел Мутјеу, Париз, 14. фебруара 1862.

${ }^{35}$ J. Ристић, нав. дело, II, 97. 
изазвала је одлука о стварању народне војске коју су туркофилске силе сматрале француским пројектом. Доказ за то била је одлука владе у Паризу да Србији пошаље мајора Иполита Мондена, чији је задатак био да организује српску војску. Именовање француског официра за министра војног било је, по оцени британског конзула Лонгворта „директан напад на Портина права и интересе“. Својим присуством и радом у Кнежевини Монден је ометао рад британског и аустријског конзула. Зато је његов одлазак из Србије био први услов за побољшање српско-турских односа. Лонгворт није примио са олакшањем вест што је француски официр, почетком маја 1862. године, најавио свој повратак у Париз. Говорило се да је он припремио све планове за образовање народне војске и да преостаје само њихово спровођење у дело. ${ }^{36}$ Кнежевину је подржавала и Русија, са којом је Француска била у споразуму. Без обзира на стварне околности, Велика Британија је сматрала да је Петроград имао одлучујући утицај у Београду а све заплете у европским провинцијама Турске приписивала је делатности руских агената. Из свих ових разлога, а подстакнуте одлукама Преображенске скупштине, Порта и туркофилске силе су одлучним и претећим држањем хтеле да предупреде свако евентуално учешће Србије у тадашњим немирима на Балкану.

За време трајања овог спора врло интересантно је било држање Русије. У изјавама њених представника било је приметно одређено неслагање. ${ }^{37}$ Наиме, за разлику од цариградског амбасадора кнеза Лобанова који је од почетка стао у одбрану Правитељства, кнез Горчаков је

36 љ. П. Ристић, нав. дело, 200-201.

37 Узрок размимоилажења у ставу Горчакова и Лобанова по питању одлука Преображенске скупштине Љиљана Алексић је видела у томе што је цариградски амбасадор добијао упутства од директора Азијског департмана, одсека Руског министарства спољних послова, потпуно одвојеног од Канцеларије овог министарства. Водећи рачуна да буде одржан општи смер политике Петрограда по Источном питању, Азијски департман је увек слао посебне инструкције амбасади у Цариграду. Каткад оне нису биле у сагласности с назорима кнеза Горчакова (љ. Алексић, нав. дело, 54). Међутим, не треба занемарити чињеницу да је у ово време Михаило био у сукобу с „руском странком“ на чијем челу су били митрополит Михаило и либерални првак Стевча Михаиловић. Користећи се тиме што Михаило није имао деце, ови његови противници су расправљали о могућности да га у датом часу замене једним руским кнезом. Овакав покушај застрашивања само је допринео учвршћењу одлуке српског владара да лично управља земљом и да не дозволи страна уплитања (Г. Јакшић, В. Вучковић, нав. дело, 101). Овај сукоб и Михаилово држање такође су могли утицати на Горчаковљев став према одлукама Преображенске скупштине. 
изјавио да је Порта формално у праву што се жали на једностране одлуке српске скупштине. Руски министар се изјаснио за наставак преговора по овим питањима започетих под кнезом Милошем. У приватном разговору, вероватно са неким од турских званичника, Горчаков је истакао да ће на то пристати и Гарашанин који се недавно из Цариграда вратио у Србију. ${ }^{38}$

Изјава кнеза Горчакова била је, међутим, само тактички потез. У току читаве 1860. године вођени су преговори између Русије и Француске о начину на који би у исто време било решено Источно и италијанско питање. Не придајући велики значај уставном питању у Србији Горчаков није видео потребу да се озбиљније заложи у корист Кнежевине. Оваквим држањем руски министар је покушао да демантује постојање споразума с владом у Тиљеријама и да отклони сумње које су у том погледу гајиле Аустрија и Велика Британија. Поред тога, препуштајући Француској улогу главне заштитнице српских интереса, Горчаков је настојао да скине с Русије одговорност за поступке Правитељства. Требало је убедити Беч и Лондон да Петроград не подстиче Кнежевину на отпор према Порти.

С друге стране, цариградски амбасадор се доследно држао општег правца спољне политике Русије у Источном питању. Та политика је подразумевала слабљење веза између Турске и њених вазалних хришћанских провинција. Што се Србије тиче, то је значило учвршћење њене унутрашње аутономије. Други аспект те политике је било споразумно иступање с Француском по питањима Истока. У случају Кнежевине било je, дакле, потребно да руски представници пруже недвосмислену подршку ставу владе у Тиљеријама, што је цариградски амбасадор и учинио. На тај начин Правитељству је стављено до знања да Србија и даље може рачунати на потпору Петрограда.

Доласком Гарашанина на чело владе остварена је пуна сарадња између Француске и Русије. Обе силе су инсистирале на томе од почетка Михаилове владавине. Ослањајући се на Француску, Гарашанин је одмах започео рад на приближавању Русији. Без обзира на споразумно иступање с Француском, влада у Петрограду је желела да докаже да је њен утицај на Истоку још увек присутан и да није одустала од заштите интереса хришћана у Турској. Руски амбасадор у Цариграду је добио наређење да иступање у вези с одлукама српске скупштине и подршку Кнежевини препусти француском амбасадору. У домаћој историографији истакнуто је мишљење да је став владе у Петрограду био различит од наклоњеног става руског амбасадора на Конференцији великих сила отвореној у Цариграду 27. септембра 1861. године, а посвећеној питању уједињења

\footnotetext{
38 Л. Ранке, нав. дело, 463.
} 
Влашке и Молдавије. Забуну је свакако изазвало најпре одлучно и оштро иступање кнеза Лобанова на првој седници ове конференције, а потом заузимање блажег става руског амбасадора, управо по налогу министра Горчакова. ${ }^{39}$ У сваком случају, Русији, као ни њеној савезници Француској, није одговарало покретање Источног питања, чије би жариште била Србија. То не би било по вољи ни туркофилским силама Аустрији и Великој Британији. Једина разлика је била у томе што су Петроград и Париз сматрали да се мир може одржати попуштањем Кнежевини, док су Беч и Лондон били мишљења да ће се Србија осилити и изазвати буру на Балкану. ${ }^{40}$

У складу са својом политиком народности, Француска је током читавог трајања спора око одлука Преображенске скупштине доследно подржавала Србију. Овакво држање било је у вези с плановима званичног Париза на Балкану и у складу с одредбама француско-руског споразума по Источном питању утемељеним на састанку царева Наполеона III и Александра II 1857. године у Штутгарту. Постојао је и предлог из 1860. године по коме би у случају пропасти Османског царства две силе заједнички радиле на стварању независних држава на Балкану. У више наврата за време овог српско-турског спора министар Тувнел је поновио страним дипломатама да је распад Турске неизбежан. ${ }^{41} \mathrm{У}$ јесен 1861. године Француска је разматрала могућност да искористи врење у Турској за истовремено решавање Источног и италијанског питања. У намери да од Аустрије као накнаду добије Венецију и уступи је Италији, влада у Тиљеријама је понудила званичном Бечу да војно интервенише у Херцеговини. ${ }^{42}$ Оба плана подразумевала су учешће Србије, па је стога њена унутрашња стабилност била у интересу Француске. У случају да буде усвојена идеја о стварању независних држава на Балкану уређена Кнежевина би свакако представљала стожер окупљања јужнословенских народа. С друге стране, због уласка аустријских трупа у Херцеговину Србија би ради заштите својих сународника свакако ступила у рат против Хабзбуршке монархије. У циљу спровођења ма ког од ових планова, Француска је желела да осигура Кнежевини унутрашњу консолидацију, учвршћење установа и да спречи даље протесте Порте, Аустрије и Велике Британије против одлука српске скупштине. Међутим, због мексичког питања околности су се убрзо промениле. Влада у Тиљеријама је

39 Д. Леовац, Србија и Русија за време друге владавине кнеза Михаила (1860 1868), Београд 2015, 72.

40 Љ. П. Ристић, нав. дело, 202.

41 Л. Ранке, нав. дело, 464.

${ }^{42}$ АСАНУ, И 20/2, И LII, Метерних Рехбергу, Париз, 12. марта 1861. 
одустала од својих планова на Балкану. Последњег дана октобра 1861. године Француска, Велика Британија и Шпанија су у Лондону потписале конвенцију о слању војне експедиције у Мексико. ${ }^{43}$ Ради спровођења планова у овој средњоамеричкој земљи влади у Паризу је сада била потребна сарадња званичног Лондона. Не треба изгубити из вида да је овде био у питању обострани интерес. Експедиција у Мексику је подразумевала и учешће британских војних снага. Због тога је Француска желела да по српском питању избегне сваку даљу расправу с туркофилском Великом Британијом. У време поласка међународних трупа за Мексико у односима између Србије и Турске владала је највећа затегнутост због одлука Преображенске скупштине. Стога, додатно компликовање Источног питања уласком Кнежевине у рат никако није одговарало Француској. Она је желела што хитније окончање спора између Србије и туркофилских сила. У том циљу Тувнел је вршио притисак на Аустрију и Велику Британију дајући изјаве о неизбежној пропасти Османског царства и стварању независних држава на њеним темељима. Из страха да би након уласка Кнежевине у рат могло доћи до поделе Турске и да би Француска била наклоњена том плану, туркофилске силе су привремено обуставиле протесте против одлука Преображенске скупштине. ${ }^{44}$ На тај начин влада у Паризу је остварила своју главну намеру. Она је допринела смањењу затегнутости између Србије и Турске и спречила додатно компликовање Источног питања у тренутку када јој је у циљу остварења планова у Мексику била потребна подршка Велике Британије.

\footnotetext{
${ }^{43}$ Dictionnaire du Second Empire, sous la direction de Jean Tulard, Paris 1995, 815. Силе су предузеле војни поход ради заштите интереса европских капиталиста који су преузели државне дугове Мексика и били оштећени због грађанског рата у тој земљи. Војна експедиција у Мексику (1862-1867) била је важна због последица које је оставила на општу политику Француске, а самим тим и на њену источну политику. На америчком континенту влада Наполеона III водила је политику ширења француског утицаја. Француска се заинтересовала за мексичко питање из три разлога: питања заштите католичких интереса, финансијског питања и питања опште политике (P. Renouvin, La politique extérieure du Second Empire, I-III, Paris 1940; II, 210).

44 љ. Алексић, нав. дело, 54-55.
} 


\section{ЛИСТА РЕФЕРЕНЦИ - LIST OF REFERENCES}

\section{Архиви - Archives}

Archives du Ministère des Affaires Etrangères (AMAE), Paris - La Courneuve. Les fonds : Correspondance politique (origines - 1896) : le sous-fond Turquie; Correspondance politique des consuls (1826-1896) : le sous-fond Turquie-Belgrade.

Архив Српске академије наука и уметности (АСАНУ), Историјска збирка - Исписи Гргура Јакшића из Архива француског министарства спољних послова. [Arhiv Srpske akademije nauka i umetnosti (ASANU), Istorijska zbirka - Ispisi Grgura Jakšića iz Arhiva francuskog ministarstva spoljnih poslova]

\section{Извори - Primary Sources}

Ристић Ј., Спољашњи одношаји Србије новијега времена, књ. I-III, Београд 1887-1901. [Ristić J., Spoljašnji odnošaji Srbije novijega vremena, knj. I-III, Beograd 1887-1901]

\section{Литература - Secondary Works}

Dictionnaire du Second Empire, sous la direction de Jean Tulard, Paris 1995.

Đorđević Ž., Čukur-česma 1862. Studija o odlasku Turaka iz Srbije, Beograd 1983.

Алексић Љ., Став Франиуске према Србији за време друге владе кнеза Милоча и Михаила (1858-1868), Београд 1957. [Aleksić Lj., Stav Francuske prema Srbiji za vreme druge vlade kneza Miloša i Mihaila (1858-1868), Beograd 1957]

Ђорђевић Ж., Српска народна војска. Студија о уређењу народне војске Србије 1861-1864, Београд 1984. [Đorđević Ž., Srpska narodna vojska. Studija o uređenju narodne vojske Srbije 1861-1864, Beograd 1984]

Јакшић Г., Вучковић В., Спољна политика Србије за владе кнеза Михаила. Први балкански савез, Београд 1963. [Jakšić G., Vučković V., Spoljna politika Srbije za vlade kneza Mihaila. Prvi balkanski savez, Beograd 1963]

Леовац Д., Србија и Русија за време друге владе кнеза Михаила (1860-1868), Београд 2015. [Leovac D., Srbija i Rusija za vreme druge vlade kneza Mihaila (1860-1868), Beograd 2015]

Љушић P., Србија 19. века. Изабрани радови, Београд 1994. [Ljušić R., Srbija 19. veka. Izabrani radovi, Beograd 1994]

Љушић Р., Историја српске државности. Србија и Црна Гора - нововековне српске државе, књ. II, Нови Сад 2001. [Ljušić R., Istorija srpske državnost. Srbija i Crna Gora - novovekovne srpske države, knj. II, Novi Sad 2001]

Поповић Б., Дипломатска историја Србије, Београд 2010. [Popović B., Diplomatska istorija Srbije, Beograd 2010]

Поповић В., Политика Франиуске и Аустрије на Балкану у време Наполеона III, ЗемунБеоград 1925. [Popović, V., Politika Francuske i Austrije na Balkanu u vreme Napoleona III, Zemun-Beograd 1925]

Ранке Л., Србија и Турска у XIX веку, Београд 1879. [Ranke L., Srbija i Turska u XIX veku, Beograd 1879]

Ристић Љ. П., Велика Британија и Србија (1856-1862), Београд 2008. [Ristić Lj. P., Velika Britanija i Srbija (1856-1862), Beograd 2008] 


\title{
Uroš Tatić
}

\section{FRENCH ATTITUDE TOWARDS THE RESOLUTIONS OF THE GREAT NATIONAL ASSEMBLY OF PREOBRAŽENJE IN 1861}

\begin{abstract}
Summary
The support that France was giving to Serbia during the Assembly of Preobraženje was connected with its policy in Italy. In autumn 1861 France was considering the option of using the tumultuous situation in Turkey in order to simultaneously solve the Eastern Question and Italian Question. Intending to obtain Venice from Austria as a compensation which would be given to Italy, the Government in Paris offered to the Habsburg Monarchy to have a military intervention in Herzegovina in order to allegedly pacify the uprising there. Although both plans included the participation of Serbia, the inner stability of the Principality was important to France. In case of adopting the idea about the creation of independent countries, Serbia would be the gathering point of Southern Slavic nations. On the other hand, if Austrian troops intervened in Herzegovina, the Principality would either way come into a war against the Danube Monarchy. In order to carry out any of the two plans, the Government in Paris wanted to ensure inner consolidation for Serbia, the strengthening of institutions, as well as to prevent further protests of Turkey, Austria and Great Britain against the resolutions of the Assembly of Preobraženje.
\end{abstract}

Keywords: Assembly of Preobraženje, Prince Mihailo, Thouvenel, Teste, France, Serbia, Turkey, the Porte.

Чланак примљен: 07. 03. 2018. Чланак коначно прихваћен за објављивање: 12. 07. 2018. 